\title{
Tourism Management in Cikondang Ancestral Hamlet
}

\author{
Adrian Agoes, S.Sos, MM.Par \\ STIEPAR YAPARI-AKTRIPA \\ J1.Dr. Ir. Sutami No. 81-83, Bandung \\ adrian.tea@gmail.com
}

\begin{abstract}
In accordance with the Bandung Regency Government's policy to initiate tourism as a way in elevating the living standard of the people, there are some villages declared as tourism village by the government. One of the villages is Lamajang Village, which has various potential for tourism. One of the attractions is the presence of a small hamlet called Cikondang known for its traditional house compound. Cikondang Ancestral Hamlet as a part of Lamajang Tourism Village in Bandung Regency, Indonesia, has very strong potentials in heritage tourism. However, this noble purpose of tourism has not reached any significant achievement. This condition clearly needs to be followed through by the society as well as the governments and tourism industry players. The effort that can be taken is to strengthen the traditional values and manage it to become attractive tourism activities that can be offered to the visitors. A very strong challenge faced in managing tour-ism activities in this hamlet is the local wisdom itself known as 'pamali' (taboo). As much interested as the visitors to experience the local tradition, the Cikondang people still strongly hold to the restrictions inherited from their ancestors. Restrictions such as the visitors cannot enter the traditional house and the forbidden forest, visitors are not allowed to have noisy activities, will hold back visitors in enjoying the tourism activities that can be offered by this hamlet. At this moment the people of Cikondang has not seen tourism to be their main activities and their main income. Some visitors do come by and the people are already familiar to become a host for them. Most of the visitors are domestic visitors such as students, college students, and researchers. The community leader is already aware that tourism can somehow be a way to elevate their standard of living, or at least be a significant additional income for some seasons. The main challenge is that the facts there are still no established market for this potential heritage tourism attraction. In this case, the development of tourism activities is confronted with preserving of the values that the people hold on to. The method used in this research is qualitative descriptive. This research is aimed to identify the heritage tourism potentials in Cikondang Ancestral Hamlet, then find a model of tourism management that can preserve the Sundanese culture of Cikondang, yet allow the people to benefit in increasing welfare through tourism activities.

Keywords-Tourism Management, Village Tourism, Cultural
\end{abstract}

Heritage, Tourist Attraction

\section{INTRODUCTION}

There is an urge to the local government in Indonesia to focusing its development to the area of the villages. Thus it is hoped that there will be a social change from urbanization to ruralization. The people from the city will be attracted to visit the village. According to that policy, the government of West Java has started to develop some area to become a tourism village (desa wisata). On that account tourism development should be projected systematically from the national level through the regency level.

The regency of Bandung, West Java, has also taken part in reflecting this policy by proclaiming some villages to become a tourism village. Besides its village activities, Bandung Regency also has strong potentials in cultural activities as well as cultural heritage. One of the potential villages is Lamajang Village, especially in Cikondang Ancestral Hamlet. The attraction offered in Cikondang is involving two dimensions, that is cultural heritage and village activities.

Cikondang also has a strong evident of the ancestor's way of living in a form of traditional house. The traditional house is said to be hundreds years of age, and had survived a big combustion shattering the village back then. The existence of Cikondang has its importance that is to become the living example of how the ancestors of Sundanese people (especially in that particular area) had lived. Cikondang can be a representative of Sundanese way of life of long ago. Visitors coming to this village can learn about the cultural value and the way of living of the Sundanese people in the past time. 
Nonetheless, there is a challenge in developing tourism activities in Cikondang, which is the continuation of the ancestors' local wisdom known as 'pamali' (or taboo). The taboo is not in favors of augmenting the tourism activities. Even though the people of Cikondang have plenty of traditional activities, but they would not allow visitors to take part of those local customs activities, especially in the site of the ancestral traditional house and in the area of forbidden forest. For that matter, in the effort of preserving the traditional values of ancestral hamlet of Cikondang, some thoughts from certain aspects are needed.

\section{METHOD}

Considering the nature of the subject in regard of tourism management and the availability of the respondent, the methodology used in this research is descriptive qualitative by selecting certain informer. In this case we have one informer who is the leader of the native people managing the site. The data collecting technique was using interview, observation, as well as literature study. The observation tools used were checklist and photography. The interview used video recording technique. The research explored the information from the informer and develop conclusion from the data collected.

\section{LITERATURE REVIEW}

\section{A. Tourism Village}

Tourism Village is a rural area that offers the whole atmosphere of village authenticity including its social-economy life, socio-cultural life, daily life activities, having specific architecture and village organization, having unique economic life, and having local potentials to be developed as tourism component such as attraction, culinary, accommodation and other tourism needs. The requirement to be a tourism village should imply the following conditions: (1) Good accessibility, (2) Having interesting objects of tourism, (3) Acceptance from host society and government, (4) Guaranteed security, (5) Availability of accommodation, telecommunication facilities, and human re-sources, (6) Having a good climate, (7) Interconnected with other tourist objects and already well known by the people (Priasukmana \& Mulyadin, 2001).

\section{B. Cultural Heritage Tourism}

In regard to the character of the site being observed, beside tourism village, the concept used in this research is related with cultural heritage.

\section{1) UNESCO definitions of heritage}

The working definition for heritage tourism constituted by UNESCO Convention for the Safeguarding of the Intangible Cultural Heritage in 2003 (ED/GE Tourism Solutions, 2010) is as follows:

The practices, representations, expressions, knowledge, skills and traditions - as well as the instruments, objects, artifacts and cultural spaces associated therewith - that communities, groups and, in some cases, individuals recognize as part of their cultural heritage as may be expressed in, but not limited to, the following domains: oral traditions, local histories as well as language; rituals, performances and social practices; indigenous and local knowledge concerning nature, the universe and human environment, and traditional craftsmanship

While in the UNESCO Convention Concerning the Protection of World Cultural and Natural Heritage in 1972 (ED/GE Tourism Solutions, 2010) some of the form of heritage is listed as 'sites'. It is defined as follows:

Sites: works of man or the combined works of nature and man, and areas including archaeological sites, which are of outstanding universal value from the historical, aesthetic, ethno-logical or anthropological point of view.

\section{2) ASEAN Cultural Heritage Requirements}

From the ASEAN Declaration on Cultural Heritage declared in Thailand by the ministers of foreign affair of ASEAN countries in the year 2000, it is noted some conditions on ASEAN level to manage a Cultural Heritage site. This includes six points that is: 1.) Uniqueness and characteristics of heritage, 2.) Site protection and conservation, 3.) Tourism and site management, 4.) Environ-mental management, 5.) Accessibility, 6.) Support facilities.

\section{3) The Importance of Tourism for Heritage Sites}

Even though in some heritage sites, the protection principles are more important, nevertheless tour-ism also plays an important role in managing a heritage 
site. The Australian Heritage Commission (AHC) stated that tourism is important as it helps to provide public access, the option for recreation, and most importantly, tourism will help to raise awareness of the value of the heritage sites. It is also said that well-informed tourists will be more willing to take action in protecting the place and also will support and respect the program in managing the heritage site. Thus, tourism is hoped to contribute to the conservation effort. As for the local community, AHC explains that tourism would provide employment opportunities as well as additional income to the local people and also to strengthen the local identity so the local will much more aware of the value of their place there-fore encourage them to maintain and protect the sites.

\section{Tourism Management}

In order to view the research from the tourism management perspective, here are the conceptual literatures used in this research:

1) Cultural Heritage Tourism Management Principle

In setting a sustainability stage for heritage tourism, it is said that a sustainability principles should be adopted (Chabra, 2010). It is defined as follows:

Having the potential to consistently advocate long-term economic, social, cultural / heritage viability, and local welfare and education while striving to become a locally inclusive, collaborative, and ecologically balanced industry.

While Boyd (2002 in Chabra, 2010) identified five themes for sustainable development in heritage industry in Canada, as follows: 1.) Mutually beneficial partnership; 2.) A national strategy with local linkage; 3.) Integration of public and private sectors; 4.) Knowledge-based local communities; 5.) Greater attention to culture and heritage within the context of a wider view of tourism in general.

In acknowledging the value of cultural heritage tourism, the following excerpt from Rosenfeld paper (2002) has a comprehensive meaning:

Cultural and Heritage Tourism is a tool of economic development that achieves economic growth through attracting visitors from outside a host community, who are motivated wholly or in part by interest in the historical, artistic, scientific or lifestyle / heritage offerings of a community, region, group or institutions (Silberberg, 1995). Such travel is focused upon experiencing cultural environments, including landscapes, the visual and performing arts and special lifestyles, values, traditions and events. There is broad agreement that cultural resources generate economic vitality by leveraging human capital and culture to generate economic vitality through tourism, crafts, and cultural attractions.

Also cultural resources may contribute to an area's "innovative habitat" by making communities more attractive to highly desirable knowledge-based employees and permitting new forms of knowledge intensive production to flourish. This may be effective not only in large central cities, but in smaller com-munities and rural areas as well. Cultural and heritage tourists stay longer and spend more money than other kinds of travelers thus making such tourism an important economic development tool (Advisory Council on Historic Preservation, 2002).

\section{CONCLUSION AND SUGGESTIONS}

\section{A. Overview of Cikondang Ancestral Hamlet}

The term ancestral hamlet is used to describe the site of traditional house and forbidden forest within the area of Lamajang tourism village. Cikondang is a hamlet included in Lamajang village.

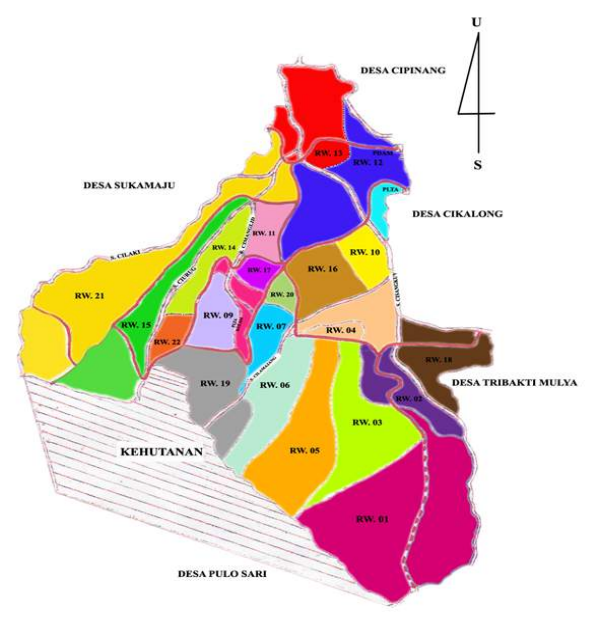

Fig. 1. Tourism Map of Lamajang Village 
The locals believed that the hamlet has been around since the year 1703 or in Islamic year 1126 Hijriah. The origin of the people in Cikondang is said to come from a nomadic farmer from the northern hill arrived at the foot of Gunung Tilu (Mount Tilu). At the time of the research, there were 250 families lived in the area of 300 hectare. In the beginning, this site in Cikondang was a compound of houses using the architectural style similar to the one seen in Bumi Adat (the main house in the site). Approximately in 1940s there were still more or less sixty houses in the hamlet. At 1942 there were immense combustion burnt almost all of the houses except the ones existed today.

The hamlet is located in the village of Lamajang at Pangalengan District, in Bandung Regency, 38 kilometers south of Bandung City. It sits by the edge of Gunung Tilu base, bordering with the wood, which is part of a preserved forest. In the preserved area, various animals can still be found such as owl, squirrel, monkeys, and also forest vegetation.

\section{B. Traditional House of Cikondang}

The ancestral house of Ki Sunda is the only heritage of Uyat Murtaki a.k.a. Ma Empuh, the first 'key holder' from the $16-17$ century in Cikondang. This house is built on the land of the ancestral (tanah ulayat) belongs to the community. This traditional elevated house has the size of $8 \times 12$ meters with a terrace-like deck on the front of the house using traditional dried coconut leaf as its rooftop. The kitchen area has a unique interlocking half-cut bamboo pipe as the rooftop. The house only has one main door with five windows. It is said that the architectural character was built based on certain social and religious values. A few meters away at the side of the house, there is a bamboo building that is used for small hall where the village leaders held meetings. At the back of the house, there is a small entrance to the forbidden forest. When entering the forest, one must take off their footwear to honor the purity of the forest. The site area is said to be officially open for tourist visit. For cultural visit, it is open everyday. But for religious visit to the sacred tomb, it only opens on Monday, Wednesday, Thursday and Sunday.

\section{Cikondang Assessment Using ASEAN Tourism Heritage Standard}

According to the standard used in ASEAN Tourism Heritage Requirements, following is the result of the assessment:

TABLE I. Assessment Using ASEAN Tourism Heritage STANDARD

\begin{tabular}{|c|c|c|}
\hline Criteria & Requirements & Observation Result \\
\hline \multirow[t]{2}{*}{$\begin{array}{l}\text { A. Uniqueness } \\
\text { and } \\
\text { characteristics } \\
\text { of heritage }\end{array}$} & $\begin{array}{l}\text { Natural Heritage } \\
\text { 1. Significance of } \\
\text { ecological } \\
\text { systems and } \\
\text { natural habitats. } \\
\text { 2. Undisturbed } \\
\text { environments or } \\
\text { environments } \\
\text { demonstrating } \\
\text { natural process at } \\
\text { work i.e. } \\
\text { wetlands, } \\
\text { wilderness areas, } \\
\text { or coastal areas. } \\
\text { Existence of rare } \\
\text { and unique } \\
\text { species present at } \\
\text { the site. }\end{array}$ & $\begin{array}{l}\text { 1. Village atmosphere such as } \\
\text { rice fields, natural stream, } \\
\text { natural forest, are still well } \\
\text { maintained and significantly } \\
\text { seen. } \\
\text { 2. Forest is still protected and } \\
\text { remains untouched as a result } \\
\text { of local cultural value. } \\
\text { 3. There are some rare animals } \\
\text { especially birds can be seen. } \\
\text { Traditional names such as } \\
\text { manintin, ancuing, sarieup, } \\
\text { canitnit, momono bids can still } \\
\text { be found. }\end{array}$ \\
\hline & $\begin{array}{l}\text { Cultural Heritage } \\
\text { 1. Significance of } \\
\text { the existing } \\
\text { cultural and } \\
\text { historical } \\
\text { resources. } \\
\text { 2. Authenticity and } \\
\text { integrity. } \\
\text { 3. Degree of } \\
\text { survival of the } \\
\text { archaeological } \\
\text { remains, human } \\
\text { values, ways of } \\
\text { life, customs, } \\
\text { land use, events } \\
\text { and living } \\
\text { traditions. }\end{array}$ & $\begin{array}{l}\text { 1. Ancestor's house sites is well } \\
\text { preserved and maintained with } \\
\text { its natural yard since its } \\
\text { establishment in the past. } \\
\text { 2. The architecture of the } \\
\text { ancestor's house is still } \\
\text { keeping the original style even } \\
\text { though has gone through minor } \\
\text { renovation to replace worn out } \\
\text { materials. } \\
\text { The people still hold the } \\
\text { ancestor's belief and } \\
\text { Sundanese values and culture. } \\
\text { 3. The originality of the } \\
\text { ancestor's house is still well } \\
\text { maintained, as well as the } \\
\text { people's way of life in village } \\
\text { life such as farming, traditional } \\
\text { ceremony, are still performed } \\
\text { in the way as their ancestor's } \\
\text { did. }\end{array}$ \\
\hline $\begin{array}{c}\text { B. Site } \\
\text { protection and } \\
\text { conservation }\end{array}$ & 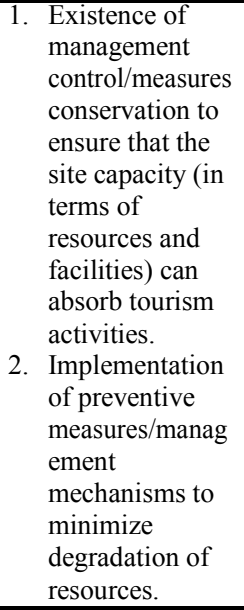 & $\begin{array}{l}\text { 1. There has not been any } \\
\text { professional management to } \\
\text { run the activities around the } \\
\text { ancestral hamlet. The } \\
\text { preservation is done } \\
\text { individually by the inheritance } \\
\text { of the house. } \\
\text { 2. There is no preventive } \\
\text { management mechanism to } \\
\text { minimize degradation of } \\
\text { resources, people only rely on } \\
\text { the ancestor's belief (taboo). }\end{array}$ \\
\hline
\end{tabular}




\begin{tabular}{|c|c|c|}
\hline Criteria & Requirements & Observation Result \\
\hline $\begin{array}{l}\text { C. Tourism } \\
\text { and site } \\
\text { management }\end{array}$ & $\begin{array}{l}\text { 1. Appropriate } \\
\text { tourism activities } \\
\text { compatible with } \\
\text { local heritage, } \\
\text { values and } \\
\text { character. } \\
\text { 2. Involvement of } \\
\text { local } \\
\text { communities in } \\
\text { the development } \\
\text { and the } \\
\text { management of } \\
\text { the cultural and } \\
\text { the natural } \\
\text { heritage site } \\
\text { 3. Creation of jobs } \\
\text { that encourage } \\
\text { the use of local } \\
\text { knowledge, skills } \\
\text { and traditions. } \\
\text { 4. The use of } \\
\text { appropriate off- } \\
\text { site and on-site } \\
\text { interpretive } \\
\text { media to educate } \\
\text { visitors such as: } \\
\text { Signage /panel, } \\
\text { Brochure, } \\
\text { Visual/ audio } \\
\text { presentation, } \\
\text { Guide book, } \\
\text { Special events } \\
\text { 5. Availability of } \\
\text { well-trained } \\
\text { local } \\
\text { guides/interprete } \\
\text { rs to serve } \\
\text { visitors. } \\
\text { program in place } \\
\text { Introduction of } \\
\text { codes of conduct } \\
\text { to educate } \\
\text { visitors on what } \\
\text { should or should } \\
\text { not do when } \\
\text { site. }\end{array}$ & $\begin{array}{l}\text { The community leader and } \\
\text { Kompepar (local tourism } \\
\text { activist group) are in effort to } \\
\text { handle the visitors. There is a } \\
\text { procedure to handle the } \\
\text { visitors but is still very simple. } \\
\text { 2. The local people are only } \\
\text { active in the cultural activity } \\
\text { when there is time for } \\
\text { ceremony, which is done } \\
\text { yearly. Also when there is a } \\
\text { group of visitors who stay at } \\
\text { their houses. } \\
\text { 3. There hasn't been significant } \\
\text { number of people who depend } \\
\text { their living on tourism. Local } \\
\text { handicrafts are yet to have } \\
\text { significant consumers. } \\
\text { 4. There is a signage at the } \\
\text { entrance on the main road, and } \\
\text { one at the alley as the access to } \\
\text { the ancestral hamlet. } \\
\text { There is no brochure, } \\
\text { interpretive media, nor any } \\
\text { guidebook available. } \\
\text { 5. There is no well trained } \\
\text { localguide. Visitors are mainly } \\
\text { handled by the community } \\
\text { leader. } \\
\text { 6. Simple introduction is } \\
\text { available through the } \\
\text { community leader explanation. } \\
\text { 7. Monitoring program is not } \\
\text { available. }\end{array}$ \\
\hline $\begin{array}{l}\text { D. } \\
\text { Environment- } \\
\text { al } \\
\text { management }\end{array}$ & $\begin{array}{l}\text { 1. } \begin{array}{l}\text { Provision of } \\
\text { appropriate and } \\
\text { sufficient waste } \\
\text { management } \\
\text { system. }\end{array} \\
\text { 2. Put in place } \\
\text { wastewater } \\
\text { treatment. } \\
\text { 3. Zoning parking } \\
\text { area for the site. } \\
\text { 4. Control and } \\
\text { regulate the entry } \\
\text { of objects, } \\
\text { materials and } \\
\text { vehicles to the } \\
\text { site. }\end{array}$ & $\begin{array}{l}\text { 1. Waste management is done by } \\
\text { local government } \\
\text { 2. Traditional wastewater system } \\
\text { 3. No parking zone. Only } \\
\text { roadside parking. The road is } \\
\text { too small for parking. } \\
\text { 4. No control and régulation for } \\
\text { entry to the objects. }\end{array}$ \\
\hline $\begin{array}{c}\text { E. } \\
\text { Accessibility }\end{array}$ & $\begin{array}{l}\text { 1. Sufficient } \\
\text { infrastructure } \\
\text { and facilities to } \\
\text { enable easy and } \\
\text { safe access to }\end{array}$ & $\begin{array}{l}\text { 1. Only village road is available. } \\
\text { There is a road sign at the } \\
\text { main road of Banjaran- } \\
\text { Pangalengan }\end{array}$ \\
\hline
\end{tabular}

\begin{tabular}{|c|c|c|}
\hline Criteria & Requirements & Observation Result \\
\hline & $\begin{array}{l}\text { the site. } \\
\text { 2. Adequate and } \\
\text { clear directional } \\
\text { signage to the } \\
\text { site. }\end{array}$ & 2. Very simple signage available. \\
\hline $\begin{array}{l}\text { F. Support } \\
\text { facilities }\end{array}$ & $\begin{array}{l}\text { 1. Adequacy of } \\
\text { facilities such as } \\
\text { medical care, } \\
\text { F\&B outlets, } \\
\text { elec-tricity, } \\
\text { water supply, } \\
\text { restrooms, } \\
\text { communication } \\
\text { tools. } \\
\text { 2. Availability of } \\
\text { skilled staff, } \\
\text { officials/ local } \\
\text { guards and other } \\
\text { measures to take } \\
\text { care of safety } \\
\text { and security for } \\
\text { visitors. }\end{array}$ & $\begin{array}{l}\text { 1. No supporting facilities are } \\
\text { available. The nearest medical } \\
\text { care is in Pangalengan district. } \\
\text { Restrooms are only available } \\
\text { using local people's house. } \\
\text { 2. No skilled staff available. } \\
\text { There is Kompepar (local } \\
\text { tourism activist group) but still } \\
\text { not in function. }\end{array}$ \\
\hline
\end{tabular}

\section{Village Life}

In general Lamajang Village has gone through some developments especially in economic aspect. The economic life which is mainly as farmers already lifted to the higher standard. Though, the atmosphere of their village life such as rice fields, fishponds in the yard, fresh air, still significantly presents. Visitors also still can see the typical villager's house, livestock, and other typical Sundanese villages' attributes. Even though the new way of planting rice is now dominant, but they still practice the ancestors' way that is planting the rice in a dry land. This way of planting rice known as 'rebon' in their language. It stands for 'Pare di Kebon' or rice in the farm. Some of the local customs are still in practice, such as 'Wuku Taun', held every Muharram month between 1 - 5 Muharram (Islamic Calendar), in the site of ancestral hamlet. Normally the local governments are invited during this ceremony. There is also a yearly event maintaining the 'Rebon' that is called 'Ruwat Selokan' maintaining the traditional irrigation for the rice in the farm. Besides the above ceremony, local values are also still in practice. One of them is the 'pamali' or taboo as stated previously "panjang ulah diteukteuk, pondok ulah disambung" (whatever grows one must not cut, whatever short one must not extend). As for the art, they also still are practicing some local art especially in music, for instance the 'Beluk', and also 'Pupuh' which are the forms of traditional singing. In general, the architectural in Cikondang is no longer supporting traditional style. 
The same goes for the village's spatial layout, which is already insignificant. However, the overall atmosphere is still representing the character of a village. Some of the houses are still using woven bamboo as the wall; some of them use wooden planks. Domestic plantations are also characterizing the village atmosphere in Cikondang.

\section{E. The Potentials of Tourism Activities in Cikondang}

Visitors can learn the history of Sundanese ancestors around the hamlet. The heritage house has valuable historic values to learn in accordance to the existence of Sundanese people. Other than that, visitors can also learn about Sundanese culture, not only in terms of art and music, but also in terms of the Sundanese value of life. Some values are also unique to Cikondang itself. Next, visitors can also experience the villagers' way of life. They can try to live in the people's house and do the usual activities of the people in Cikondang, especially as farmers. Another thing is that visitors can learn some 'traditional workshop' where they can learn how to create interesting traditional local crafts. Even they can learn how to do simple daily work such as peeling coconuts or making traditional delicacies. The last is that visitors who stayed at Cikondang can explore further within the Lamajang Village that is home to various natural attractions. Visitors can do soft adventure activities such as hiking, visiting waterfalls, or even do river rafting that is already organized by local operators from Bandung Regency.

\section{F. Challenges in Managing Tourism in Cikondang Ancestral Hamlet}

There are six main challenges identified in managing tourism in Cikondang.

- First is the local value. The people of Cikondang still hold strong to local wisdom and taboo thus visitors, especially foreigners, cannot enjoy visiting the traditional house site and the forbidden forest. Some of the musical potential also cannot be performed around the site.

- Second, the economic development has led to the modernization in the people's lifestyle. If this is not managed well, Cikondang might loose the uniqueness of their village life.

- Third, lack of visitors management system. Visitors simply come to the house of the community leader, listen to his explanation and see the site. Maximum experience has yet to be obtained by visitors.

- The fourth challenge is lack of human resources who is trained in tourism activities. Even though there is Kompepar (community of tourism activists), yet there hasn't been any valuable program to enhance the human resources here.

- The fifth is lack of people's understanding in what tourism is. In term of its activities, or its benefits, as well as its negative impacts and how to prevent or overcome it.

- The last challenge is that there hasn't been any ideal market developed for this destination. Current market consists of students and researchers, also pilgrims, who bring insignificant contribution to welfare of the people of Cikondang.

\section{G. Suggestions in Tourism Management in Cikondang}

In spite of the challenges identified in managing tourism in Cikondang, this research has found some recommendation that should be act upon to improve the tourism management in this hamlet. There are three important recommendations as follows:

- As in heritage concept preservation is more important than tourism activities, the head of Cikondang hamlet has come out with unexpected recommendation to re-create the ancestral hamlet (especially the traditional house complex) in different zone. This re-creation of the traditional house complex has the purpose to serve the visitors needs to experience all kinds of the activities which is forbidden in the actual heritage house. This research suggests that the concept of recreation should be developed under the concept of re-establishment program. In which to make it as authentic real Cikondang families will actually inhabit the re-created house. This way, the ancestral hamlet can still be visited, yet, prevented from being overused by the visitors, as the taboo will still be in effect. In order to have the visitors to be able to experience the local culture in authentic environment, they could come to the reestablishment complex to have the similar layout, architecture, and the overall environment. It is strongly suggested that this re-establishment complex should have similar area of 'forbidden forest' that visitors could enter this area.

- Another recommendation is to have consistent coaching in tourism activities, which in this case would be in the interest of the local government. 
Before developing the ideal market, the people of Cikondang should be prepared predominantly by tourism knowledge and skill. There are two main areas that should be trained those are visitors management technique, and also hospitality skill. Those will be very useful to host the visitors who want to stay at the local people's house. Training in guiding and interpretation technique is also of importance and can be useful for the people of Cikondang.

- Thus, the third recommendation is to develop the ideal market, who typically visit heritage attraction as in other heritage attractions. Cikondang needs to have the right type of visitors' profile who can bring real benefits to the people through valuable tourism activities.
Even though it is also important, but preventing modernization can be difficult. Especially when the people of Cikondang has not place reliance on tourism activities as their source of income. However, local tradition is still well maintained from generation to generation, strengthen by the help from the local government.

\section{REFERENCES}

[1] Priasukmana, Soetarso \& Mulyadin, R.M., "Pembangunan Desa Wisata: Pelaksanaan Undang-undang Otonomi Daerah,” in Info Sosial Ekonomi, vol. II No. 1, 2001 (references)

[2] N.n., City of Cape Town, Phase 2: Situation Analysis Final Report, ED/GE Tourism Solutions, retrieved on January 10, 2015 from https://www.capetown.gov.za/en/tourism/Documents/Tourism_CHTS_F rwrk_Final_Phase_2_Nov_2012.pdf

[3] N.n., ASEAN Declaration on Cultural Heritage. Bangkok, Thailand, 2000.

[4] N.n., Successful Tourism at Heritage Places (A Guide For Tourism Operators, Heritage Managers, and Communities). Australian Heritage Commission \& Industry Science Resources, retrieved on January 10, 2015 from https:/www.environment.gov.au/system/files/resources/945d855d-855b44f2-9140-9eb85dc7d4ac/files/successful-tourism.pdf

[5] Chabra, Deepak, Sustainable Marketing of Cultural and Heritage Tourism, Routledge, 2010.

[6] Rosenfeld, R.A., "Cultural and Heritage Tourism", Eastern Michigan University, retrieved on February 2012 from http://citeseerx.ist.psu.edu/viewdoc/download?doi=10.1.1.505.2157\&rep $=$ rep $1 \&$ type $=$ pdf (n.d.)

[7] Pedersen, Arthur, Managing Tourism at World Heritage Sites: a Practical Manual for World Heritage Site Managers, UNESCO World Heritage Centre, 2002.

[8] Timothy, D \& Nyaupane, G., Cultural Heritage and Tourism in The Developing World, Routledge, 2009. 